Abstracta Iranica Abstracta Iranica

Revue bibliographique pour le domaine irano-aryen

Volume 40-41 | 2019

Comptes rendus des publications de 2017-2018

\title{
Laurianne Martinez-Sève. "Les opérations d'Antiochos III en Bactriane-Sogdiane : l'apport de la documentation archéologique"
}

Michele Minardi

\section{(2) OpenEdition Journals}

Electronic version

URL: http://journals.openedition.org/abstractairanica/50138

DOI: 10.4000/abstractairanica.50138

ISBN: 1961-960X

ISSN: 1961-960X

Publisher:

CNRS (UMR 7528 Mondes iraniens et indiens), Éditions de l'IFRI

Electronic reference

Michele Minardi, "Laurianne Martinez-Sève. "Les opérations d'Antiochos III en Bactriane-Sogdiane :

l'apport de la documentation archéologique"'”, Abstracta Iranica [Online], Volume 40-41 | 2019,

document 48, Online since 30 December 2019, connection on 20 April 2021. URL: http://

journals.openedition.org/abstractairanica/50138 ; DOI: https://doi.org/10.4000/abstractairanica. 50138

This text was automatically generated on 20 April 2021.

Tous droits réservés 


\title{
Laurianne Martinez-Sève. "Les opérations d'Antiochos III en Bactriane-Sogdiane : l'apport de la documentation archéologique"
}

\author{
Michele Minardi
}

\section{REFERENCES}

Laurianne Martinez-Sève. "Les opérations d'Antiochos III en Bactriane-Sogdiane : l'apport de la documentation archéologique" in Chr. Feyel, L. Graslin-Thomé (eds.). Antiochos III et l'Orient. Actes de la rencontre franco-allemande tenue à Nancy du 6 au 8 juin 2016. Paris : Éditions de Boccard, 2018, p. 271-302

1 This paper by Laurianne Martinez-Sève presents an overview of the anabasis of Antiochus III (208-206 BC), an undertaking in the Upper Satrapies of his kingdom that enabled him to assume the traditional title of Great King. The paper is a state-of-the-art discussion of what is known about the campaign of this important Seleucid ruler. In discussing the evidence available, which is unfortunately scant, the author had to start with Polybius's account of the king's campaign; it is our main literary source in this regard. Martinez-Sève, using Polybius's chronological timeline, argues about the geography and the toponyms assigned by the Greek historian in the three most relevant fragments of his record that have survived to this day (X, 49; XI, 34; and XXIX, 12). The author details the events that occurred from the end of the offensive in $209 \mathrm{BC}$ against Arsaces II of Parthia to the ensuing clash at the river Arios (the Heri-Rud River of today's Afghanistan) with the army mustered by the Graeco-Bactrian king Euthydemus I. Further, she analyses the events in progress during the spring of $206 \mathrm{BC}$, that is, the Seleucid siege of Bactra. Although this city is not explicitly mentioned before Book XXIX, it is very likely the place in which Euthydemus sought sanctuary, as emphasised by the author. The siege of Bactra is dealt with by Polybius in the third key 
passage of his narration (XXIX, 12). At this point, the ancient historian is no longer dealing with the anabasis. The vulgate believes that the mention of the siege in this passage, along with other great sieges, has to be viewed in light of its particular importance. But Martinez-Sève disagrees with this interpretation, underlining the fact that evidence is missing for the reconstruction of the succession of events in Antiochus's campaign and the duration of the siege itself, as is traditionally done. This first section of the paper is followed by a discussion of archaeological data, mostly numismatics with up-to-date references. The author argues then that Antiochus was likely active in several other areas of Bactra and not only in the long biennial siege of its capital. She contemplates the possibility that the invading king was also active in Ai Khanoum, a city that still had at the time a key role among the Seleucid foundations of Asia. The hypotheses of J.D. Lerner and B. Lyonnet on the relation between Antiochus's presence and the corresponding phase of the life of the city are discussed. The renovation of the most important ceremonial space of the city, the Sanctuary, might have been linked to the presence of the Seleucid king, although the intervention of Diodotus I (or of his son) remains the more plausible explanation for this event (p. 287). Nevertheless, the information on the Seleucid anabasis suggests that the GraecoBactrians at the end of the 3rd century BC could resist the Seleucid power, that they were strengthening their positions in the east in close contact with their neighbours and in preparation for their Indian campaigns, and that Euthydemus's victorious resistance, and his recognition as king, helped him consolidate his power and pursue his ambitious plans.

\section{AUTHORS}

\section{MICHELE MINARDI}

Centre of Classical and Oriental Archaeology, Moscow 